\title{
Representasi Identitas Melalui Komunikasi Visual Dalam Komunitas Virtual Palanta Urang Awak Minangkabau
}

\author{
Elda Franzia \\ FSRD Universitas Trisakti \\ Jl. Kyai Tapa No. 1, Jakarta 11440 \\ Yasraf Amir Piliang, Acep Iwan Saidi \\ Sekolah Pascasarjana Institut Teknologi Bandung \\ Jl. Ganesha No. 10, Bandung 40125
}

\begin{abstract}
In virtual community, identity represented through various form. A person as community member is appearing through profile picture and doing communication activity between members in virtual community. The communication held actively in verbal and visual communication form consists of message exchange and meaning through symbols that understand thoroughly based on culture and custom with certain characteristic differ to each ethnic groups. Palanta Urang Awak Minangkabau is one of the virtual communities in Facebook social network. As an active virtual community, the communication is ongoing intensely between members. Conversation and interaction are often beginning with image posting by member. This research is aim to explain the variety of visual communication form in this certain virtual community as part of virtual identity construction of Minangkabau ethnic group. The method is virtual observation and documentation, with semiotic method analysis in cultural studies approach. This research gave the understanding of image typology and cultural symbolism in Minangkabau culture, especially in the context of virtual community in Facebook.
\end{abstract}

Keywords: identity, communication, visual, Minangkabau, Facebook

\begin{abstract}
ABSTRAK
Dalam komunitas virtual, identitas direpresentasikan melalui berbagai bentuk. Individu yang menjadi anggota komunitas dihadirkan melalui foto profil dan melakukan aktivitas komunikasi antar individu dalam ruang komunitas virtual tersebut. Komunikasi berlangsung secara aktif meliputi tukar menukar pesan dan pemaknaan secara verbal dan visual melalui simbol-simbol penandaan yang dipahami bersama, dengan berbasis budaya dan adat dengan karakteristik tertentu yang berbeda antara etnis satu dengan yang lain. Palanta Urang Awak Minangkabau merupakan salah satu komunitas virtual di jejaring sosial Facebook. Sebagai komunitas virtual yang aktif, komunikasi berlangsung secara intens antar anggotanya. Percakapan dan interaksi sering kali dimulai dengan gambar yang dipaparkan oleh anggota komunitas. Kajian ini bertujuan untuk memaparkan ragam bentuk dan cara penyampaian komunikasi visual di dalam komunitas virtual ini sebagai bagian dari konstruksi identitas virtual etnis Minangkabau. Metode yang digunakan adalah observasi dan dokumentasi virtual, melalui analisis semiotik dengan pendekatan cultural studies. Kajian ini memberi pemahaman terhadap tipologi gambar dan simbol-simbol budaya yang berlaku dalam adat Minangkabau, khususnya dalam konteks komunitas virtual di Facebook.
\end{abstract}

Kata kunci: identitas, komunikasi, visual, Minangkabau, Facebook 


\section{PENDAHULUAN}

Jejaring sosial Facebook telah dikenal sebagai media komunikasi interaktif di masyarakat Indonesia sejak tahun 2009. Sejalan dengan perkembangan teknologi informasi, khususnya telepon seluler yang menjadi alat komunikasi saat ini, penggunaan Facebook sebagai media interaksi semakin luas. Facebook dapat diakses dengan mudah, baik melalui komputer maupun melalui telepon seluler yang terkoneksi dengan internet. Pengguna menjadi semakin tidak berbatas oleh jarak dan waktu, terhubung antara satu dengan yang lain dalam ruang virtual, sesuai dengan tujuan yang terungkap dalam tagline Facebook yaitu "Facebook Helps You Connect and Share With People in Your Life" (Fariz:2009).

Dalam publik jejaring sosial yang sedemikian luas, komunitas virtual memberi ruang bagi homogenitas di dalam ruang publik yang heterogen. Homogenitas yang terbentuk dari latar etnis yang sama memungkinkan anggota komunitas virtual saling memahami karena berkomunikasi dalam bahasa yang sama, menyampaikan pesan yang sama, melalui simbol-simbol yang dipahami bersama oleh anggota komunitas tersebut. Homogenitas dalam komunitas virtual ini menyatukan beragam anggota komunitas yang berasal dari berbagai tempat yang berbeda dan berjarak, sesuai dengan sifat ruang virtual yang terbuka dan cair.

Palanta Urang Awak Minangkabau merupakan salah satu komunitas virtual yang terbentuk di jejaring sosial Facebook. Komunitas virtual ini terbentuk sebagai ruang berkumpul dan bercakap di dunia maya yang diperuntukkan untuk memupuk persaudaraan bagi masyarakat Minangkabau di mana pun berada. Prinsip persaudaraan itu berlandaskan pada empat pilar yang harus dibina secara baik, yaitu: ta'aruf (saling mengenal), tafahum (saling memahami), ta'awun (saling menolong), dan tarahum (saling menyayangi). Palanta sendiri mengandung arti tempat bercakapcakap, di mana segala topik bisa diperbincangkan, mulai dari persoalan dapur dan adat hingga politik dan berita aktual. Sebagai komunitas virtual yang bersifat terbuka, Palanta Urang Awak Minangkabau menerima keanggotaan dari berbagai kalangan yang dipersatukan oleh etnis yang sama, yaitu Minangkabau. Anggota komunitas ini berjumlah 11.319 anggota pada Desember 2013 dan mengalami peningkatan pesat menjadi 31.320 anggota pada September 2014 dengan 5.120 foto yang diunggah.

Anggota komunitas hadir dalam bentuk representasi foto profil dan nama akun sebagai identitas virtualnya. Setiap anggota komunitas dapat memulai percakapan di dalam dinding (wall) komunitas, baik dalam bentuk pesan visual melalui foto yang diunggah (image posting) maupun pesan verbal. Komunikasi dalam komunitas virtual ini berlangsung aktif dan interaktif. Pesan yang disampaikan akan diterima oleh anggota komunitas yang sedang log in dalam jejaring sosial Facebook. Pesan yang menarik akan ditanggapi oleh anggota komunitas, baik dalam bentuk tanda suka (Like) maupun komentar (comment). Percakapan akan berlangsung apabila komentar dari satu anggota ditimpali dengan komentar anggota lain yang mempercakapkan tentang apa yang disampaikan oleh anggota komunitas mula-mula.

Jejaring sosial Facebook menjadi media komunikasi sosial yang populer dalam masyarakat masa kini. Media merepresentasikan bagaimana dunia dikonstuksi dan direpresentasikan kepada kita dalam 
bentuk praktik hidup sehari-hari yang direpresentasikan dalam berbagai teks. Untuk itu, guna memahami fenomena masyarakat, kajian media, termasuk media jejaring social, merupakan kajian yang terus terbuka bagi berbagai kemungkinan pengayaan keilmuan. Kajian ini bertujuan untuk memaparkan ragam bentuk dan cara penyampaian komunikasi visual intraetnis di dalam komunitas virtual ini. Objek kajian adalah gambar-gambar di ruang komunitas virtual Palanta Urang Awak Minangkabau yang menjadi pesan komunikasi visual sebagai bagian dari representasi identitas etnis masyarakat Minangkabau di ruang virtual.

\section{METODE}

Metode yang digunakan adalah observasi dan dokumentasi virtual, melalui analisis semiotik dengan pendekatan cultural studies. Kajian media merupakan bagian penting dalam cultural studies. Eksplorasi teks visual merupakan cara memahami materi representasi kultural di sekitar kita. Teks visual akan membentuk makna melalui berbagai objek, citra, bunyi, dan praktik yang merupakan sistem tanda (Barker, 2011:12). Kajian menggunakan data kuantitatif yang kemudian dianalisis secara kualitatif. Pengumpulan data dilakukan melalui metode observasi terhadap aktivitas komunitas virtual di jejaring sosial Facebook. Keseluruhan aktivitas komunikasi antaranggota komunitas tersebut diamati secara khusus, dimulai dari gambar yang diunggah pada dinding komunitas. Gambar-gambar yang menjadi pesan visual tersebut kemudian didokumentasikan. Hasil dokumentasi dikategorisasi berdasarkan topik gambar dan percakapan verbal antaranggota komunitas.

Analisis dilakukan melalui uraian elemen-elemen pada gambar tersebut, termasuk pesan, kode, dan elemen visual yang digunakan dalam membentuk gambar. Elemen-elemen tersebut kemudian direlasikan dengan identitas virtual dalam konteks budaya dan adat masyarakat Minangkabau. Hasil analisis memaparkan penggunaan elemen-elemen komunikasi visual pada komunitas virtual yang menggunakan kode budaya yang dipahami anggota komunitas tersebut sebagai bagian dari representasi identitas virtual masyarakat etnis Minangkabau.

\section{HASIL DAN PEMBAHASAN}

Perkembangan teknologi komunikasi informasi menghadirkan ruang baru dalam masyarakat, yaitu ruang virtual. Dalam ruang virtual, diri hadir selama terkoneksi melalui komputer dan jaringan internet. Media dan teknologi membentuk konteks dan situasi di mana identitas baru dikonstruksi. Identitas yang tidak hanya diwariskan secara biologis, historis, dan geografis, tetapi juga dibentuk dari teks, bahasa, representasi visual, dan narasi individu. Dengan demikian salah satu kekuatan identitas virtual menurut Tim Jordan adalah identity fluidity (Nasrullah, 2012:129). Identitas di ruang virtual yang bersifat cair, di mana individu dapat membentuk identitas online berdasarkan teks deskriptif sebagaimana diinginkan.

Teknologi ini juga memfasilitasi munculnya komunikasi lewat komputer yang dikenal sebagai CMC (computer-mediated communication). Salah satu prinsip utama CMC yang disebutkan oleh Jones (1995) adalah bahwa komunikasi melalui komputer memungkinkan suatu bentuk ruang yang diproduksi secara sosial, yaitu ruang virtual. Marc Smith (1995) menyebutkan empa) aspek interaksi virtual yang membentuk perilaku komunikasi yang berlangsung pada CMC , yaitu: (a) interaksi virtual bersifat aspasial, tidak mengenal ruang dan jarak, 
(b) interaksi virtual bersifat asinkorn, tidak beriringan, (c) CMC bersifat acorporeal, tidak jasmaniah, dan (d) CMC bersifat astigmatic, meniadakan diferensiasi sosial berdasarkan stigma sosial (Holmes, 2012:126-129).

Keempat karakteristik CMC tersebut menyebabkan komunikasi antarmasyarakat dalam ruang virtual berlangsung dalam proses interaksi dan integrasi antarmasyarakat jejaring. Manuel Castells mengungkapkan bahwa media yang menghimpun masyarakat jejaring mengotak-ngotakkan masyarakat dalam segmentasi. Media tersebut membentuk lingkungan yang homogen, hidup bersama dalam ruang yang sama, berbagi pengalaman dan pikiran, seperti laiknya kehidupan masyarakat tribal. Hal tersebut bertentangan dengan realitasnya, di mana masyarakat yang berada dalam satu jaringan saling berelasi dalam kampungnya masingmasing, bukan dalam satu kampung global yang tunggal (Eymeren, 2014:139).

Komunikasi itu sendiri merupakan proses kultural yang berlandaskan pada sistem signifikasi. Umberto Eco menyebutkan bahwa proses komunikasi merupakan perpindahan sebuah sinyal termasuk tanda-tanda yang dibawanya dari sebuah sumber menuju sebuah tujuan. Manakala tujuan tersebut adalah manusia di mana sumber yang tidak selalu manusia menyampaikan sinyal yang didasarkan pada kaidah-kaidah yang diketahui dan diakui manusia sebagai penerima, maka proses tersebut adalah proses signifikasi. Proses signifikasi tersebut merangsang respons interpretif pada diri penerima yang dimungkinkan oleh adanya kode-kode tertentu yang diterima manusia sebagai tujuan komunikasi tersebut (Eco, 2009:9).

Komunikasi visual menggunakan gambar atau teks visual sebagai media komunikasinya. Bentuk komunikasi visual yang lazim digunakan pada media jejaring sosial Facebook adalah gambar berupa foto. Hal ini dimungkinkan karena pada jejaring sosial Facebook terdapat fasilitas untuk menggunggah foto dalam dinding pemilik akun dan komunitas yang diikuti olehnya. Gambar menambah unsur kemenarikan sebuah percakapan, atau gambar menjadi pembuka percakapan itu sendiri. Pada gambar terdapat rangkaian tanda-tanda yang digunakan sebagai pengantar pesan. Tanda-tanda tersebut menjadi bermakna apabila antara pengirim pesan dan penerima pesan dalam konteks komunikasi visual tersebut berbicara dalam bahasa yang sama, atau dengan kata lain menggunakan kodekode budaya yang dipahami bersama. Mitos, legenda, adat istiadat, juga sistem kekerabatan, dapat menjadi kode budaya masyarakat etnis tertentu. Kode budaya tersebut yang kemudian digunakan dalam komunikasi intraetnis dalam komunitas masyarakat etnis tertentu. Mengacu pada semiotika Saussure, pada sistem komunikasi visual, kode menjadi langue dan elemenelemen visual pada gambar menjadi parole.

Proses produksi tanda juga bergantung pada media pengantar pesannya. Jejaring sosial mengakomodasi tanda visual atau nonverbal sebagai pengantar bahasa visual dan tanda verbal sebagai pengantar bahasa verbal dalam interaksi komunikasi penggunanya. Bahasa verbal tetap menjadi objek primer dalam komunikasi. Eco menyebutkan bahwa meskipun bahasa verbal lebih kuat, bahasa verbal tidak sepenuhnya mampu memenuhi syarat efabilitas (keterungkapan) yang dibutuhkan oleh penyampai pesan (Eco, 2009:262). Kebutuhan pemenuhan efabilitas tersebut yang mungkin dipenuhi oleh bahasa visual. Bahasa visual dapat menambah makna penyampaian pesan melalui elemen-elemen visual pada gambar seperti warna, garis, 
bidang, dan huruf. Gambar membentuk signifikansi dari apa yang ada di luar gambar tersebut. Cara kita melihat sebuah subjek dipengaruhi oleh apa yang kita ketahui dan kita percayai. Gambar merupakan tanda yang membawa pesan komunikasi.

Foto sebagai salah satu bentuk gambar dapat dengan mudah ditangkap oleh mata. Seperti dikatakan John Berger, apa yang tampil secara visual akan ditangkap, dikenali, dan diterima lebih cepat dari apa yang hadir secara verbal (Berger, 1972:7). Hal ini sesuai dengan karakteristik media jejaring sosial seperti Facebook, yang juga berlaku khususnya dalam komunitas virtual di dalamnya, di mana percakapan antaranggota pada umumnya berawal dari adanya unggahan pada dinding komunitas, baik unggahan berupa pesan verbal maupun pesan visual. Unggahan berupa gambar (foto) lebih mudah mendapat perhatian berupa Like dan comment yang akhirnya memancing percakapan selanjutnya atau komunikasi intraetnis dalam komunitas tersebut. Like menjadi tanda adanya perhatian terhadap unggahan anggota komunitas tersebut, sedangkan comment yang berlanjut menjadi tanda keberhasilan anggota komunitas menjalin komunikasi dan juga menarik perhatian anggota komunitas yang lain.

Apabila dikaitkan dengan sirkuit komunikasi yang dikembangkan oleh Hall dalam Davis dan Walton (2010:292), proses komunikasi dalam komunitas virtual tersebut mengalami tiga fase komunikasi. Fase tersebut adalah: (a) fase pengkodean, yaitu kondisi institusional media yang mengatur kebijakan media sebagai medium teks verbal dan visual, (b) fase penyampaian pesan, yaitu teks yang dikonstruksi sebagai pesan dalam proses komunikasi, dan (c) sase pendekodean, yaitu penerimaan dan konsumsi pesan oleh publik.

\section{Tipologi Visual Komunikasi Visual di dalam Komunitas Virtual}

Berdasarkan pengamatan yang dilakukan pada 100 gambar yang diunggah pada dinding komunitas virtual Palanta Urang Awak Minangkabau, terdapat 10 kategori gambar berdasarkan tema gambar, yaitu : (a) kuliner, (b) kostalgia, (c) gurauan, (d) alam, (e) Islam, (f) politik, (g) petuah adat, (h) komersil, (i) event, dan (j) foto diri. Berdasarkan kuantitas kategori gambar, maka kategori Kuliner, Nostalgia, dan Gurauan, merupakan tiga jenis kategori gambar yang terbanyak diunggah di dinding komunitas virtual tersebut, seperti dipaparkan pada diagram di bawah ini.

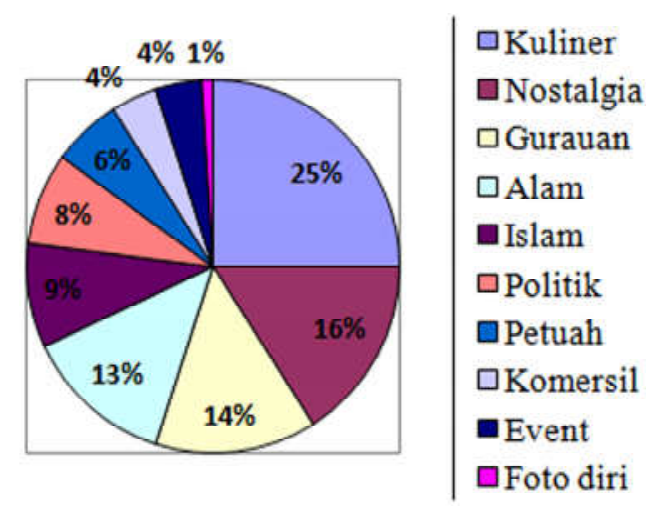

Gambar 1.

Kategori Gambar Unggahan Berdasarkan Tema Gambar

Sedangkan berdasarkan jenis gambar yang diunggah, dapat dibedakan menjadi 4 jenis gambar, yaitu : (a) foto secara langsung, (b) foto reproduksi, (c) foto dari sumber lain, dan (d) gambar digital. Dari hasil pengamatan terhadap aktivitas komunikasi visual di jejaring sosial Facebook, teknologi digital saat ini memungkinkan pengguna internet dan 
telepon seluler saat ini untuk dengan mudah mengambil gambar, baik dengan cara memotret secara langsung maupun mengambil gambar hasil unggahan orang lain. Selain itu, foto hasil cetakan pada masa fotografi analog juga dapat direproduksi secara digital. Foto atau gambar yang ada juga dapat diolah kembali dengan proses digital untuk menambah, mengurangi, merubah gambar yang asli. Perubahan berupa penambahan dan pengurangan gambar tersebut antara lain dimaksudkan untuk memberi penekanan atau penambahan informasi pada gambar yang telah ada.

\section{Representasi Identitas Melalui Komunikasi Visual di dalam Komunitas Virtual}

Identitas memberi definisi mengenai siapa diri kita dan bagaimana kita berelasi dengan orang lain dalam relasi perbedaan. Identitas diri sebagai individu tidak bisa dilepaskan dari dunia sosiologisnya. Oleh karena itu, identitas bersifat personal dan sosial, di mana secara personal identitas diwarisi dari keturunan biologis yang menentukan usia, gender, ras, penampilan biologis individu, sedangkan secara sosial identitas dipelajari melalui peniruan dan bahasa dalam kehidupan sosial individu tersebut yang menentukan status, kondisi sosial dan budaya individu.

Berikut dipaparkan bentuk-bentuk komunikasi visual intraetnis yang menjadi representasi identitas dan berlangsung di dalam komunitas Palanta Urang Awak Minangkabau.

Gambar 2 di bawah ini merupakan contoh foto-foto unggahan dengan topik kuliner yang terdapat pada dinding komunitas virtual tersebut. Foto-foto tersebut membuka percakapan dalam palanta, melalui topik kuliner yang ringan dan membangkitkan kenangan dan relasi individu dengan kampung halamannya. Topik kuliner memang kerap mendapat perhatian dari anggota komunitas lain. Mulai dari Like yang diberikan oleh anggota komunitas lain sampai dengan interaksi yang terjadi dalam komentar-komentar yang diungkapkan.


Gambar 2.

Foto Unggahan dengan Topik Kuliner

(Sumber : Dokumentasi pribadi, Facebook, 2014) 
Identitas individu direpresentasikan melalui foto profil dan nama pemilik akun yang tampil pada saat foto diunggah di dalam dinding komunitas. Walaupun foto diri individu tidak secara langsung menampilkan atribut Minangkabau seperti busana adat ataupun rumah adat yang relatif dikenal, nama pemilik akun merupakan nama-nama yang merepresentasikan individu beretnis Minangkabau. Foto profil menjadi teks visual dan nama menjadi teks verbal, dan keduanya menjadi penanda atas identitas individu dalam konteks komunikasi di dalam ruang virtual ini.

Komunikasi dilakukan melalui teks verbal dan teks visual. Konteks budaya dihadirkan oleh penggunaan bahasa dan ruang komunitas virtual yang beranggotakan masyarakat etnis Minangkabau. Teks verbal menjadi pengantar teks visual berupa foto-foto makanan yang diunggah oleh anggota komunitas. Teks verbal menggunakan bahasa pengantar Minangkabau yang merupakan bahasa pengantar umum digunakan pada komunikasi dalam komunitas ini.

Teks verbal menyampaikan sapaan, atau pembuka percakapan antaranggota komunitas virtual ini. Seperti percakapan yang terjadi di dunia nyata, percakapan bisa dimulai dari ungkapan, informasi, maupun pertanyaan, yang kemudian mendapat tanggapan dari mitra komunikasinya. Pada Gambar 2 percakapan terjadi setelah anggota komunitas yang menggunggah foto tersebut mengungkapkan kegemaran anggota komunitas yang menggunggah foto terhadap jariang (jengkol) yang lezat tetapi kerap menimbulkan masalah sosial bagi yang mengonsumsinya karena menyebabkan napas berbau, ataupun informasi nama buah yang dikonsumsi semasa kecil, ataupun juga pengetahuan mengenai makanan khas Minangkabau yang dianggap sebagai pembuktian keabsahan anggota komunitas virtual sebagai urang Minang. Oleh karena itu pernyataan dan pertanyaan ini terbuka kepada seluruh anggota komunitas Palanta Urang Awak Minangkabau.

Komunikasi yang dimulai oleh anggota komunitas yang mengunggah foto tersebut merupakan bentuk komunikasi visual di dalam komunitas virtual. Perkembangan teknologi telepon seluler saat ini memberi kesempatan dan kemudahan untuk secara langsung mengabadikan sekaligus langsung mengunggah foto tersebut ke media jejaring sosial. Sebagai teks visual adalah foto-foto makanan, berupa sepiring penuh lauk jariang (jengkol) dengan warna dan pencahayaan yang menonjolkan bumbu dan merahnya cabai dan gulai olahan lauk tersebut, buah gajus (sejenis jambu monyet) yang segar tergantung di pohon, dan sepiring kareh-kareh (sejenis kudapan renyah) sebagai pendamping bercakap di palanta. Dalam pemotretan makanan, warna dan tekstur makanan yang tervisualisasikan mendekati nyata akan dapat lebih menggugah selera bagi yang melihatnya.

Masyarakat Minangkabau memiliki pepatah yang berbunyi mato condong ka nan rancak, salero condong ka nan lamak, yang berarti mata suka melihat kepada yang indah dan selera suka pada makanan yang enak (Fitriani, 2012). Oleh karena itu, makanan Minang banyak menampilkan warna merah dan kuning yang menarik perhatian, baik dari cabai maupun bumbubumbu yang lain, sehingga menampilkan warna yang menarik di samping rasa yang lezat.

Kode yang digunakan pada komunikasi intraetnis ini adalah kode budaya, berupa bahasa dan budaya kuliner masyarakat Minangkabau. Bahasa merupakan 
unsur penting dalam kebudayaan, yang mencerminkan masyarakat dan kehidupannya. Penggunaan bahasa daerah pada komunikasi intraetnis merupakan penanda identitas dan keterikatan pada komunitas etnis pada ruang virtual yang takberbatas ini. Penggunaan bahasa daerah yang secara umum hanya dapat dipahami oleh masyarakat etnis Minangkabau telah memberi batasan komunikasi dan menciptakan homogenitas komunikasi dalam lingkungan jejaring sosial yang heterogen. Sedangkan makanan, menjadi bagian dari budaya Minangkabau yang diwariskan secara turun temurun dari generasi ke generasi dan menjadi gaya hidup yang kontekstual sifatnya. Makanan menjadi bagian penting dalam acara adat maupun sebagai pengikat dalam keluarga.

Selain gambar yang dihasilkan dari pemotretan secara langsung objek foto, gambar juga dapat berupa foto reproduksi dari hasil cetakan pada masa fotografi analog. Hasil reproduksi tersebut yang diunggah oleh anggota komunitas, seperti pada Gambar 3 di bawah ini. Berbeda dengan Gambar 2, teks verbal yang disampaikan bukan saja menggunakan bahasa Minangkabau melainkan juga menggunakan bahasa Inggris. Kode budaya yang disampaikan di sini adalah modernitas dan kekinian, sebagai kontradiksi atas masa lalu. Sesuai dengan fungsi teks verbal yang digunakan untuk memperkuat teks visual, maka teks verbal di sini memberi penekanan akan perbedaan dulu dan sekarang, masa lalu dan masa kini.

Penanda masa lalu adalah elemen warna pada teks visual, yaitu warna foto hitam putih ataupun sepia yang dikono-tasikan dengan masa lalu, sesuai dengan perkembangan teknologi fotografi analog saat itu yang belum dapat memproduksi foto berwarna. Selain itu, penampilan subjek pada foto juga menjadi penanda waktu lampau, yaitu dari gaya busana, model rambut, dan tampilan latar. Penanda lokasi adalah teks verbal Biruang Agam dan teks trayek angkutan umum Bukittinggi - Padang yang terdapat pada gambar. Objek benda pada foto yaitu
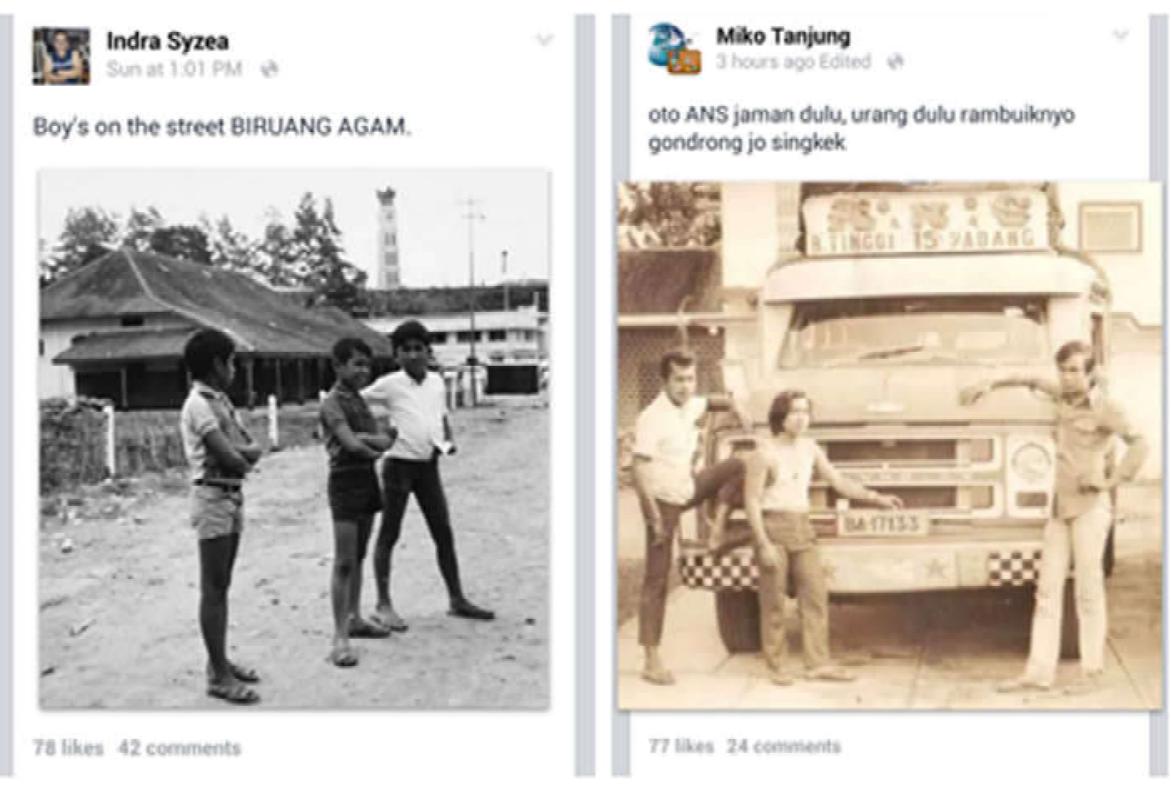

Gambar 3.

Foto Unggahan dengan Topik Nostalgia

(Sumber : Dokumentasi pribadi, Facebook, 2014) 

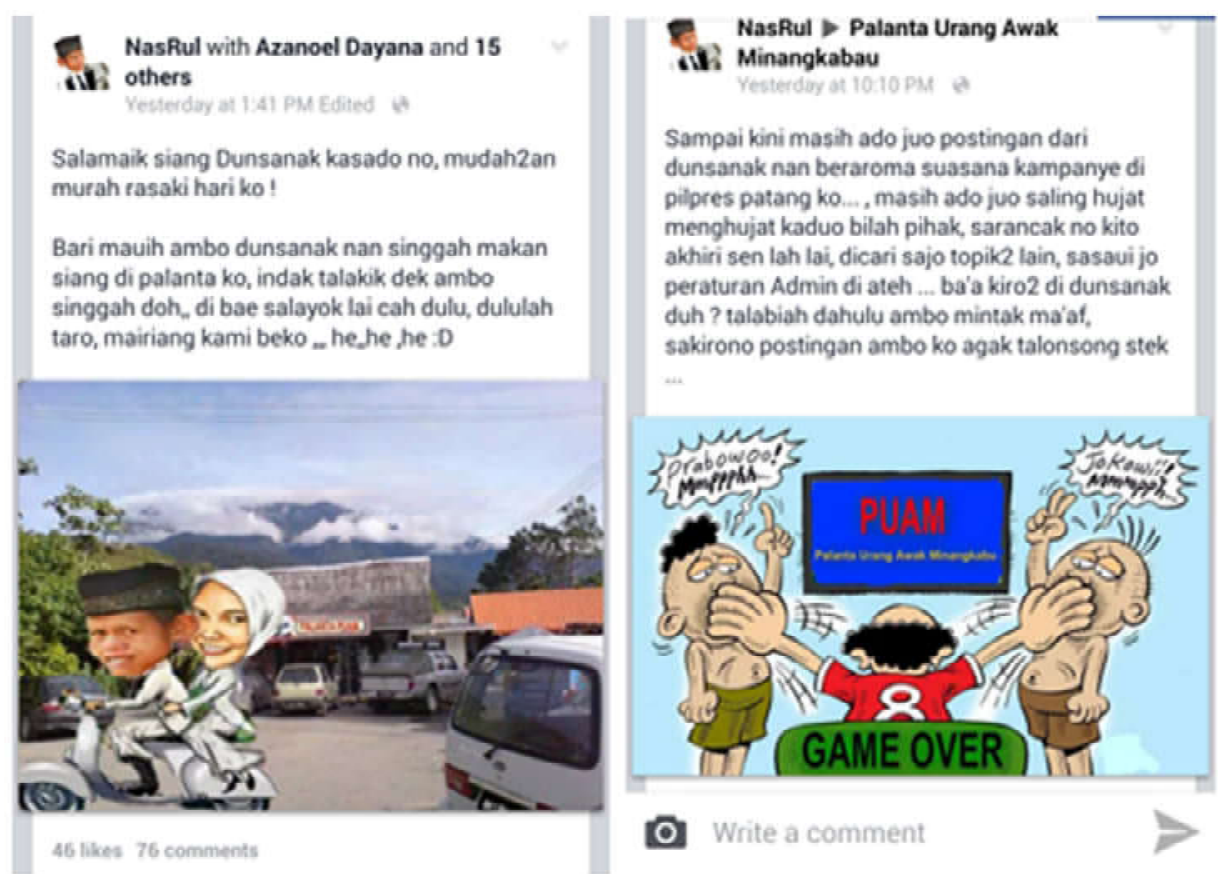

Gambar 4.

Foto Unggahan dengan Topik Gurauan

(Sumber : Dokumentasi pribadi, Facebook, 2014)

Jam Gadang di Bukittinggi sebagai elemen latar dan oto ANS yang berplat nomor BA (plat nomor Sumatera Barat) memberikan informasi lokasi pemotretan ketiga pemuda Minang ini.

Gambar 2 dan Gambar 3 merupakan foto yang diunggah oleh pemilik akun yang merupakan anggota komunitas Palanta Urang Awak Minangkabau untuk disampaikan secara terbuka kepada anggota komunitas lainnya di dinding komunitas. Hal ini berbeda dengan Gambar 3 di bawah ini, di mana pemilik akun mengunggah gambar dengan menyapa anggota komunitas lain melalui tag. Tag menyebabkan anggota komunitas lain mengetahui pada saat gambar diunggah. Tag menjadikan komunikasi tidak hanya bersifat terbuka kepada seluruh anggota komunitas yang lain, tetapidisampaikan sekaligus secara khusus kepada pemilik akun lain yang di tag untuk secara langsung ditanggapi sebagai mana fungsi pesan tertulis.
Teks verbal menggunakan bahasa Minangkabau, berisi sapaan Selamat Siang kepada seluruh handai taulan teriring doa kemurahan rezeki bagi semuanya, serta ajakan untuk singgah sejenak di palanta. Teks visual merupakan gambar digital, hasil olahan foto dengan penambahan objek ilustrasi digital berupa pemilik akun dan pasangannya yang sedang berkendara sebagai objek utama foto. Penambahan objek ini memberikan penekanan terhadap pesan visual dan pesan verbal, untuk meluangkan waktu singgah di palanta di tengah kesibukan bekerja sehari-hari. Selain itu gambar karikatural dengan topik gurauan politik juga ditujukan kepada seluruh anggota komunitas untuk tidak lagi saling menghujat dalam komunitas ini terlepas dari hasil pemilu yang telah lewat. Gambar ilustrasi berfungsi untuk memperjelas maksud dan tujuan dari pesan di samping fungsi estetisnya. Sedangkan gambar karikatural selain menampilkan 
kelucuan juga berisi kritikan dan sindiran terhadap wacana sosial yang berlangsung di masyarakat.

Secara keseluruhan sistem komunikasi visual pada komunitas virtual Palanta Urang Awak Minangkabau dapat dijelaskan dalam skema berikut di bawah ini.

Anggota komunitas (A) menyampaikan pesan kepada anggota komunitas lain secara terbuka melalui dinding komunitas (seluruh anggota komunitas). Pesan berupa gambar atau teks visual yang ditambah dengan teks verbal sebagai penjelasan atau pengantar gambarnya. Gambar berisi subjek foto dan latar, dengan warna (tone) gambar secara keseluruhan serta sudut pandang (angle) tertentu yang menjadi penanda waktu, tempat, dan peristiwa gambar tersebut. Teks visual mendukung proses komunikasi sehingga mampu memenuhi syarat efabilitas (keterungkapan) yang dibutuhkan oleh penyampai pesan. Teks verbal yang menjadi pengantar pada umumnya menggunakan bahasa Minangkabau, yang dipahami oleh anggota komunitas yang lain. Topik yang diperbincangkan adalah hal-hal yang dekat dengan kehidupan masyarakat Minangkabau, baik dalam hal pemahaman adat, lingkungan, kehidupan masa kecil di kampung halaman, maupun kehidupan saat ini di perantauan.

Seperti disebutkan oleh Umberto Eco, proses komunikasi merupakan perpindahan sebuah sinyal termasuk tanda-tanda yang dibawanya dari sebuah sumber menuju sebuah tujuan. Tujuan komunikasi di sini adalah anggota komunitas menunjukkan keterlibatannya dalam komunitas virtual ini, menjadi bagian dari masyarakat Minangkabau di ruang virtual. Tujuan komunikasi tersebut tersampaikan melalui sinyal-sinyal komunikasi yang membawa tanda, dengan memanfaatkan kode budaya masyarakat Minangkabau. Penerima yang memahami kode budaya tersebut, dapat menerima pesan yang disampaikan dan memberikan respon atas pesan yang disampaikan tersebut. Dengan kata lain, komunikasi antarmasyarakat dalam ruang virtual dapat berlangsung karena terjadi proses interaksi dan integrasi serta pemahaman bersama antarmasyarakat jejaring.

Identitas anggota komunitas yang menyampaikan pesan direpresentasikan melalui nama pemilik akun dan foto profilnya. Selain itu, bahasa yang

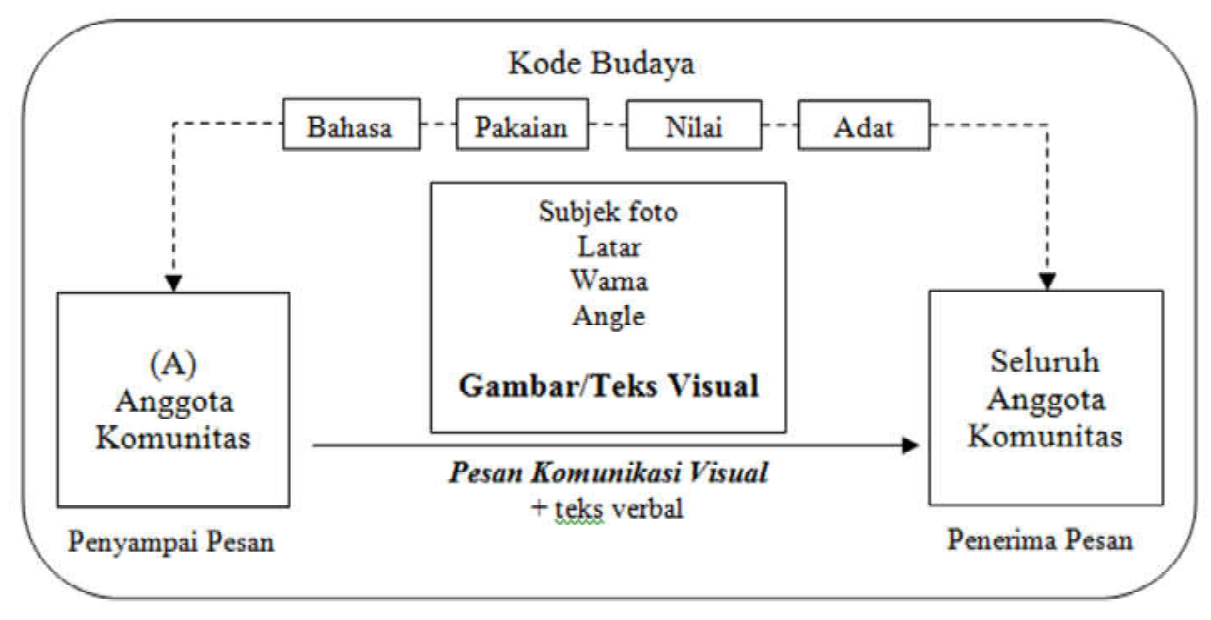

Gambar 4. 
digunakan sebagai bahasa pengantar, pakaian adat yang digunakan oleh sebagian anggota komunitas, serta adat kebiasaan masyarakat Minangkabau yang menjadi topik perbincangan yang disampaikan melalui komunikasi visual di dalam komunitas ini, juga menjadi bentuk-bentuk representasi identitas masyarakat Minangkabau di ruang virtual. Sebagaimana dikatakan oleh Tim Jordan, identitas di ruang virtual bersifat cair, di mana individu dapat membentuk identitas online berdasarkan teks deskriptif sebagaimana diinginkan. Identitas terkonstruksi, baik secara langsung maupun tidak langsung. Komunitas virtual yang disebut sebagai open community secara tidak langsung membatasi diri dengan laku penyampaian dan pembicaraan yang hanya dapat dipahami oleh orang-orang yang menggunakan kode-kode budaya yang sama, yaitu kode budaya etnis Minangkabau.

\section{SIMPULAN}

Proses komunikasi dalam komunitas virtual Palanta Urang Awak Minangkabau memenuhi 3 (tiga) fase komunikasi yang disebutkan oleh Hall, yaitu: (a) fase pengkodean, berupa kondisi media yang memberi peluang unggahan teks dan foto pada dinding komunitas virtual tersebut, (b) fase penyampaian pesan, berupa teks verbal dan teks visual yang diunggah oleh anggota komunitas, dan (c) fase pendekodean, yaitu penerimaan dan konsumsi pesan verbal dan visual oleh anggota komunitas.

Pesan verbal dan visual yang disampaikan oleh anggota komunitas meliputi berbagai tema yang cukup beragam. Dari sepuluh tema gambar yang diunggah dan terangkum dalam penelitian ini, terdapat beberapa tema yang tingkat kekerapannya tinggi dalam komunikasi visual intraetnis di dalam komunitas ini. Tema-tema tersebut adalah tema kuliner, nostalgia, dan gurauan. Ketiga tema tersebut adalah tematema yang ringan dan menghibur, yang sesuai dengan kode budaya ruang virtual yaitu palanta sebagai tempat berbincangbincang saat melepas lelah. Ruang palanta sebagai ruang informal di mana hal-hal yang dibicarakan adalah hal-hal yang menimbulkan keakraban antaranggotanya. Gambar-gambar yang digemari akan mendapat Like dan komentar dari banyak anggota komunitas yang lain. Pengalaman perhatian yang dialami oleh anggota komunitas tersebut mendorong anggota komunitas lain untuk mendapat perhatian dan reaksi yang sama.

Konstruksi identitas masyarakat etnis Minangkabau yang direpresentasikan dalam media jejaring sosial Facebook, khususnya pada komunitas virtual Palanta Urang Awak Minangkabau, tidak dapat dilepaskan dari faktor tradisi sosial budaya masyarakat Minangkabau itu sendiri. Bahasa sebagai teks verbal dan gambar sebagai teks visual merepresentasikan masyarakat etnis Minangkabau yang terikat pada adat dan tradisi. Adat menjadi faktor penggerak kehidupan pada masyarakat Minangkabau. Percakapan pada masyarakat saat ini pada konteks media baru seperti media jejaring sosial tidak lepas dari pengaruh tradisi dan kesadaran akan diri sebagai bagian dari masyarakat adat Minangkabau. Melalui gambar sebagai bentuk komunikasi visual, anggota komunitas Palanta Urang Awak Minangkabau telah mengonfirmasi diri sebagai bagian dari masyarakat etnis Minangkabau di ruang jejaring sosial Facebook selain melalui foto profil juga melalui aktivitas komunikasi interaktif yang dipahami bersama dan terjalin di antara anggota komunitas virtual tersebut. 


\section{Daftar Pustaka}

Barker, Chris

2011 Cultural Studies: Teori \& Praktik. Terj. Nurhadi, cetakan ketujuh. Yogyakarta: Kreasi Wacana.

Berger, John

1972 Ways of Seeing. Penguin Books: London.

Davis, Howard dan Walton, Paul

2010 Bahasa, Citra, Media. Terj. Ikramullah Mahyuddin. Yogyakarta: Jalasutra.

Eco, Umberto

2009 Teori Semiotika: Signifikasi Komunikasi, Teori Kode, Serta Teori Produksi - Tanda. Terj. Inyiak Ridwan Muzir. Yogyakarta: Kreasi Wacana.

Erda Fitriani

2012 "Pola Kebiasaan Makan Orang Lanjut Usia, Studi Kasus Penderita Penyakit Hipertensi Sukubangsa Minangkabau di Jakarta". Humanus. Jurnal Ilmu Humaniora, Vol. XI No. 2.

Eymeren, Margawati van

2014 Media Komunikasi dan Dampaknya terhadap Kebudayaan. Jakarta: Pusat Kajian Filsafat dan Pancasila.

Faris, A.

2009 "Demam Facebook Bagian Gaya Hidup Modern?". Artikel dalam Rubrik Lifestyle, Bintaro-BSD News.

Holmes, David

2012 Teori Komunikasi: Media, Teknologi, dan Masyarakat. Terj. Teguh Wahyu Utomo. Yogyakarta: Pustaka Pelajar.

Rulli Nasrullah

2012 Komunikasi Antarbudaya, di Era Budaya Siber. Jakarta: Kencana Prenada Media Group. 